\title{
Proteins secreted by Day-16 to -18 bovine conceptuses extend corpus luteum function in cows*
}

\author{
J. J. Knickerbocker $\dagger \|$, W. W. Thatcher†, F. W. Bazer $\ddagger$, M. Drost§,

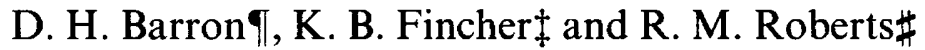

Departments of $†$ Dairy Science, $\ddagger$ Animal Science, $\S$ Reproduction, $\uparrow$ Obstetrics and Gynecology, and \#Biochemistry and Molecular Biology, University of Florida, Gainesville, Florida 32611, U.S.A.

Summary. Corpus luteum function, interoestrous interval and spontaneous uterine PGF-2 $\alpha$ (PGF) production were evaluated in 9 cyclic Holstein cows (3/group) after intrauterine injections of pooled conceptus secretory proteins, $5 \beta$-pregnan-3 $\alpha$-ol-20one, or homologous serum proteins on Days 15.5 through 21 after oestrus. A significant extension of corpus luteum lifespan and interoestrous interval were detected in cows treated with conceptus secretory proteins compared to the other 2 groups. CL lifespan and interoestrous interval were not different $(P>0.25)$ between $5 \beta$-pregnan$3 \alpha$-ol-20-one and control groups. Evaluation of spontaneous PGF responses suggested that proteins synthesized and secreted by the bovine conceptus accommodate luteal maintenance during early gestation via an attenuation of endometrial PGF production.

\section{Introduction}

An essential manifestation of pregnancy in large domestic species is extended corpus luteum (CL) function. During the first 15-16 days of pregnancy in cattle, progesterone production by the CL establishes a complex uterine environment essential for conceptus (embryo plus extraembryonic membranes) growth and development. Embryos may be transferred, and pregnancies established, as late as Day 16 or 17 after oestrus (Betteridge, Eaglesome, Randall \& Mitchell, 1980). Consequently, the presence of a conceptus within the uterine lumen before Day 16 is not a requirement for initiation of an embryotrophic uterine environment. Beyond this point, however, a viable conceptus within the uterine lumen must play an active role in the perpetuation of its embryotrophic environment by maintenance of the CL (Northey \& French, 1980; Betteridge et al., 1980; Dalla Porta \& Humblot, 1983).

The conceptus of the cow produces an array of potential 'signals' during early pregnancy, including steroids (Shemesh, Milaguir, Ayalon \& Hansel, 1979; Chenault, 1980; Gadsby, Heap \& Burton, 1980; Eley, Thatcher, Bazer \& Fields, 1983), prostaglandins (Shemesh et al., 1979; Lewis, Thatcher, Bazer \& Curl, 1982) and proteins (Bartol et al., 1984). However, conceptus factors responsible for luteal maintenance during early pregnancy and their mechanisms of action have not been demonstrated clearly in cattle. Numerous studies have evaluated the effect of prostaglandin E-2 (PGE-2) on luteal maintenance in cattle with mixed results. Administration of PGE-2 into the uterine lumen alone (Gimenez \& Henricks, 1983; Chenault, 1983) or in combination with oestradiol-17 $\beta$ (Reynolds, Robertson \& Ford, 1983) extends luteal function only slightly beyond the cessation of intrauterine PGE-2 treatments. In addition, systemic progesterone concentrations declined within $12 \mathrm{~h}$ after PGE-2 treatment (Gimenez \& Henricks, 1983) or during the treatment

\footnotetext{
*Reprint requests to $\mathrm{Dr} \mathrm{W}$. W. Thatcher.

॥Present address: Department of Physiology and Biophysics, Colorado State University, Fort Collins, CO 80523, U.S.A.
} 
period (Reynolds et al., 1983), suggesting that PGE-2 (plus oestradiol-17ß) will not prevent production and transfer of uterine luteolytic substances, but affects luteal function directly (Marsh, 1970; Henderson, Scaramuzzi \& Baird, 1977; Reynolds et al., 1981). Others have reported no effect of intrauterine PGE-2 administration on CL maintenance in cattle (Dalla Porta \& Humblot, 1983; Chenault, Van Ravenswaay \& Campbell, 1984).

Extension of CL maintenance and cycle length were demonstrated after intrauterine administration of conceptus homogenates to cyclic cattle (Northey \& French, 1980). Likewise, extracts and homogenates of sheep conceptuses (Rowson \& Moor, 1967; Ellinwood, Nett \& Niswender, 1979; Martal, Lacroix, Loudes, Saunier \& Wintenberger-Torres, 1979) or conceptus secretory proteins (Godkin, Bazer, Thatcher \& Roberts, 1984b) have been shown to extend CL function and cycle length when administered into the uterine lumen of cyclic ewes. However, luteotrophic and/or antiluteolytic actions or major conceptus-produced steroids and proteins have not been evaluated in cattle. The objectives of the present experiment were to examine the effects of a major steroid produced by the cow conceptus (Eley et al., 1983), 5 $\beta$-pregnan-3 $\alpha$-ol-20-one, and bovine conceptus secretory proteins on luteal function, cycle length and spontaneous uterine PGF production in cyclic cattle.

\section{Materials and Methods}

Conceptus collection and culture. Dairy and beef cows $(\mathrm{N}=49)$ served as conceptus donors after being mated during oestrus (Day 0). Between Days 16 and 18 after mating (17.2 \pm 0.6 days), the uterine horn ipsilateral to the CL-bearing ovary was nonsurgically flushed (Bartol et al., 1981). A French Foley catheter (size no. 16, 18 or 20; American Hospital Supply, Jacksonville, FL) was inserted through the cervical os and positioned at the base of the uterine horn just anterior to the uterine body. Sterile phosphate-buffered saline (pH 7.4; PBS; Dulbecco \& Vogt, 1954) was warmed to $37^{\circ} \mathrm{C}$ and injected into the uterine lumen at a volume of $60 \mathrm{ml}$ per flush. Medium containing conceptuses $\left(n=33\right.$ ) was collected into sterile glass containers, maintained at $37^{\circ} \mathrm{C}$, and transported to the laboratory within $30 \mathrm{~min}$ of recovery. After the last uterine flush, $20 \mathrm{ml}$ of an antibiotic solution (aqueous Procaine Penicillin G; 300000 units/ml; Pfizer Incorporated; New York, NY) were infused into the uterine lumen, and the Foley catheter was removed. Donor cows were mated and flushed up to 3 times during successive oestrous cycles.

An additional 4 cows were superovulated, mated and slaughtered at 17 days post coitum. The uterus was removed after exsanguination, sealed in a plastic bag, and placed on ice while being transported to the laboratory (within $60 \mathrm{~min}$ of slaughter). Uterine horns were trimmed of excess tissue, ovaries and oviducts were removed, and a large, curved, Rochester-Ochsner forcep was applied to the anterior cervix. The anterior tip of the uterine horn ipsilateral to the CL containing ovary was cut to provide an enlarged opening. A plastic, $50-\mathrm{ml}$ syringe fitted with an 18-gauge needle was used to administer two $30-\mathrm{ml}$ flushes (sterile PBS, warmed to $37^{\circ} \mathrm{C}$ ) into the uterine lumen through the tip of the uncut uterine horn. Medium containing conceptuses was collected into sterile plastic culture dishes. About 15-20 conceptuses were obtained by culturing conceptuses from the superovulated cows. All conceptuses, collected either nonsurgically or at post-mortem flush, were washed in and transferred to sterile culture dishes containing $15 \mathrm{ml}$ of warm Minimum Essential Medium (MEM; GIBCO, Grand Island, NY) supplemented with non-essential amino acids (GIBCO), antibiotic/antimycotic (GIBCO), 200 units insulin/1 (Sigma Chemical Co., St Louis, MO) and $1 \mathrm{~g}$ glucose/1 (Fischer Scientific; Orlando, FL). Conceptuses were cultured for $24 \mathrm{~h}$ on a rocker platform (Bellco Glass Company, Vineland, $\mathrm{NJ}$ ) and maintained at $37^{\circ} \mathrm{C}$ in a gaseous environment of nitrogen:oxygen:carbon dioxide (50:45:5, by vol.). After incubation for $24 \mathrm{~h}$ tissues and medium were separated by centrifugation $(10000 \mathrm{~g} ; 20 \mathrm{~min})$ at $4^{\circ} \mathrm{C}$. Medium (supernatant) from each culture was collected and frozen individually. Conceptus wet weights were recorded. 
Preparation of material for intrauterine injections. Medium from individual incubations (15 ml) was dialysed (Spectrapore 6, $1000 M_{\mathrm{r}}$ cutoff, Spectrum Medical Industries, Los Angeles, CA) extensively (4 1 changed thrice daily for 5 days) against $10 \mathrm{~mm}$-Tris-HCl buffer, $\mathrm{pH} 7 \cdot 2$ (Tris). After dialysis, an aliquant of medium from each culture $(n=47)$ was used for determination of protein concentration (Lowry, Rosebrough, Farr \& Randall, 1951). All culture medium was then pooled and concentrated by ultrafiltration $\left(1000 M_{\mathrm{r}}\right.$ cutoff; Amicon Corporation, Danvers, MA) to a volume of $\sim 75 \mathrm{ml}$. The concentrated filtrate was processed through a sterilization filter unit $(0.45 \mu \mathrm{m}$ pore size; Sybron/Nalgene, Rochester, NY) and dispensed into $2-\mathrm{ml}$ samples designated as pooled conceptus secretory proteins (CSP) at a protein concentration of $740 \mu \mathrm{g} / 2 \mathrm{ml}$.

A serum sample from each experimental animal $(\mathrm{N}=9)$ was collected on Day 10 of the oestrous cycle. Serum samples were dialysed individually, diluted in Tris and sterilized as described for CSP. Equal masses $(740 \mu \mathrm{g})$ of homologous serum proteins were added to each $2 \mathrm{ml}$ injection of CSP ( 3 cows; 12 injections/cow; Group 1).

Two milligrams of $5 \beta$-pregnan-3 $\alpha$-ol-20-one ( $5 \beta-\mathrm{P})$ were dissolved in $2 \mathrm{ml}$ ethanol and mixed with $80 \mathrm{ml}$ Tris. Ethanol was evaporated from the solution using $\mathrm{N}_{2}$ gas and gentle heating. The steroid solution was sterilized as described previously and dispensed into $2 \mathrm{ml}$ aliquants $(50 \mu \mathrm{g}$ each). Homologous serum proteins $(740 \mu \mathrm{g})$ were added to each $2 \mathrm{ml}$ injection of $5 \beta-\mathrm{P}$ ( 3 cows; 12 injections/cow; Group 2). Group 3 cows $(\mathrm{N}=3$ ) received homologous serum proteins alone $(1480 \mu \mathrm{g} / 2 \mathrm{ml}$ Tris; 12 injections/cow $)$. All treatment mixtures were frozen $\left(-20^{\circ} \mathrm{C}\right)$ until time of intrauterine injection.

Animal preparations. Nine cyclic Holstein cows were assigned randomly to the three previously described treatment groups. Animals were prepared for surgery (Wolfensen et al., 1985) on Day 10 of the oestrous cycle. Utilizing a midventral laparotomy, the uterus and ovaries were exposed and location of the CL were recorded. A sterile polyvinyl catheter (V-6; Bolab Incorporated, Lake Havasu City, AZ) was inserted via an incision in the isthmus of the oviduct and secured $30-50 \mathrm{~mm}$ into the anterior portion of the uterine lumen, ipsilateral to the CL. The catheter was exteriorized via a small flank incision. An additional catheter (Silastic tubing, i.d. $1.57 \mathrm{~mm}$, o.d. 3.18 mm; Dow Corning Corporation, Midland, MI) was advanced about $1.07 \mathrm{~m}$ into the saphenous vein to a position in the dorsal vena cava slightly anterior to the point of utero-ovarian venous drainage. Jugular catheterizations (V-9; Bolab) were performed, if necessary, at the time of vena cava catheter failure during the experiment. Antibiotics (Polyflex, $167 \mathrm{mg} / \mathrm{ml}$; Bristol Laboratories, Syracuse, NY) were administered on the day of surgery ( $10 \mathrm{ml}$ i.m., $10 \mathrm{ml}$ i.p. and $1 \mathrm{ml}$ intrauterine) and 1 day after surgery ( $10 \mathrm{ml}$ i.m. and $1 \mathrm{ml}$ intrauterine).

Function of the $\mathrm{CL}$ was monitored by measuring plasma progesterone concentrations from blood samples collected twice daily (08:00 and 20:00 h) beginning on Day 12 and continuing until detection of oestrus. Three acute bleedings were conducted to monitor spontaneous uterine prostaglandin (PG) production. Plasma concentrations of PGF were measured in blood samples withdrawn every $15 \mathrm{~min}$ from $08: 00$ to $14: 00 \mathrm{~h}$ on Days 18-20. Intrauterine injections of experimental materials ( $2 \mathrm{ml}$; see above) were begun at $20: 00 \mathrm{~h}$ on Day 15 and continued every $12 \mathrm{~h}$ until 08:00 h of Day 21. All animals were fitted with oestrus detection devices (KaMar Incorporated, Steamboat Springs, CO), maintained on pasture in the presence of an intact bull, and observed 2-4 times daily for oestrous behaviour. Corpus luteum regression was verified by rectal palpation after oestrus. At the end of the experiment, all animals were slaughtered and reproductive tracts dissected to assess utero-ovarian condition and catheter placement.

Progesterone and prostaglandin radioimmunoassay. Progesterone was measured in heparinized plasma samples utilizing a specific antiserum generated in sheep against progesterone conjugated to bovine serum albumin (BSA) at the C11-position. $\left[1,2,6,7-{ }^{3} \mathrm{H}(\mathrm{N})\right]$ progesterone (sp. act. $97 \mathrm{Ci} / \mathrm{mmol}$ ) was purchased from New England Nuclear (Boston, MA). Cross-reactivity of the progesterone antiserum was $<1 \%$ with $17 \alpha$-hydroxyprogesterone, 20 $\alpha$-hydroxyprogesterone, $20 \beta$-dihydroxyprogesterone, cortisol, testosterone, androstenedione and oestradiol-17 $\beta$. Standard 
curves were prepared by adding known amounts of radioinert progesterone to phosphate-buffered saline (pH 7.4) containing $1 \mathrm{~g}$ gelatin/l (PBSg). The final concentrations of progesterone were: 0 , $15 \cdot 6,31 \cdot 2,62 \cdot 4,125,250,500$ and $1000 \mathrm{pg} / 100 \mu \mathrm{l}$ PBSg. Utilizing an antiserum dilution of 1:35000, sensitivity of the assay was $15.6 \mathrm{pg}$. A plasma sample containing $\sim 4.5 \mathrm{ng}$ of immunoreactive progesterone $/ \mathrm{ml}$ was measured in triplicate into sample volumes of $50,100,200$ and $300 \mu l$. Progesterone from plasma samples was extracted by vortexing for $2 \mathrm{~min}$ with $2 \mathrm{ml}$ freshly distilled benzene--hexane $(1: 2 \mathrm{v} / \mathrm{v})$. Solvent containing the extracted progesterone was dried under $\mathrm{N}_{2}$ and brought to a $500 \mu \mathrm{l}$ assay volume with the addition of PBSg. A quantitative linear recovery was achieved $[y=20 \cdot 965+4 \cdot 111 x ; y=$ concentration of progesterone $(\mathrm{pg} / 100 \mu \mathrm{l})$ and $x=$ plasma volumes extracted $(\mu 1)$ ]. No significant differences were found between concentrations of progesterone $(\mathrm{pg} / 100 \mu \mathrm{l})$ measured using volumes of $50,100,200$ or $300 \mu \mathrm{l}(P>0.25)$. Exogenous progesterone was added to a plasma sample (mean $=1.8 \mathrm{ng} / \mathrm{ml}$ ) at doses of $0,0.5,1.0,5.0$ and $10 \mathrm{ng} / \mathrm{ml}$. All doses were replicated 4 times. A linear regression equation of added vs measured progesterone $[y=1626.1+1.0855 x ; y=$ amount of progesterone measured $(\mathrm{pg} / \mathrm{ml})$ and $x=$ amount added $\left.(\mathrm{pg} / \mathrm{ml}) ; R^{2}=0.975\right]$ described differences among concentrations. The intraassay coefficient of variation (CV) for the validation was $13.4 \%$. Intra- and interassay CVs for 8 assays were: 10.4 and $7.5 \%$, respectively, when duplicate estimates were run in the assays for a $100 \mathrm{pg} / 500 \mu \mathrm{l}(94 \cdot 2 \pm 4 \cdot 3 \mathrm{pg} / 500 \mu \mathrm{l})$ reference plasma sample, and $6 \cdot 1$ and $4 \cdot 3 \%$, respectively, when duplicate estimates were run for a $250 \mathrm{pg} / 500 \mu \mathrm{l}(269 \cdot 5 \pm 7 \cdot 0 \mathrm{pg} / 500 \mu \mathrm{l})$ sample of reference plasma.

PGF was assayed in unextracted plasma samples $(50,100$ and $200 \mu \mathrm{l})$. Concentrations of PGF were determined in a dextran-coated charcoal radioimmunoassay system previously validated for use in our laboratory (Wolfenson et al., 1985). Antiserum used in the assay was generated in goats against PGF conjugated to bovine serum albumin at the $\mathrm{Cl}$-position. This antiserum crossreacts $53.6 \%$ with PGF- $1 \alpha$ and $<1 \%$ with 15-keto-PGF-2 $\alpha$, 15-keto-13,14-dihydro-PGF-2 $\alpha$ (PGFM), PGE-1, PGE-2 and arachidonic acid. Sensitivity of the assay was $10 \mathrm{pg} /$ tube. The intra- and interassay CVs for 13 assays were: 20.0 and $12.7 \%$, respectively, when duplicate estimates were run for a $50 \mathrm{pg} / 200 \mu \mathrm{l}(60.9 \pm 2.5 \mathrm{pg} / 200 \mu \mathrm{l})$ plasma reference, and 10.6 and $5.6 \%$, respectively, when duplicate estimates were run for a $500 \mathrm{pg} / 200 \mu \mathrm{l}(489 \cdot 9 \pm 10 \cdot 1 \mathrm{pg} / 200 \mu \mathrm{l})$ plasma reference.

Statistical analyses. Data for progesterone and PGF concentrations in plasma, and accumulated PGF were analysed using the General Linear Models procedure of the Statistical Analysis System (SAS Institute Incorporated, 1982) for a split-plot analysis of variance with repeated measurements over time. Analysis of variance considered variability due to treatment (CSP, $5 \beta-P$ and Control), cow nested within treatment, time (for progesterone: Days 12-38.5; for PGF: samples 1-75 which consisted of 25 samples on each of Days 18-20), treatment by time interaction,

Table 1. Effects of intrauterine treatments with conceptus secretory

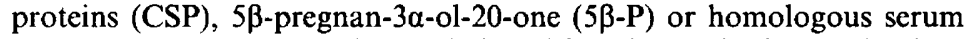
proteins (Control) on cycle length, luteal function and PGF production

\begin{tabular}{llll}
\hline Treatment & $\begin{array}{c}\text { Cycle length } \\
\text { (days) }\end{array}$ & $\begin{array}{c}\text { Days with } \\
\text { progesterone } \\
>1 \mathrm{ng} / \mathrm{ml}\end{array}$ & $\begin{array}{c}\text { Mean accumulated } \\
\text { PGF (pg/cow/day) }\end{array}$ \\
\hline CSP & $33 \cdot 4 \pm 2 \cdot 5^{* *}$ & $30 \cdot 3 \pm 1 \cdot 9^{* *}$ & $39 \pm 35^{* *}(6) \dagger$ \\
$5 \beta-P$ & $24 \cdot 7 \pm 0 \cdot 8$ & $22 \cdot 7 \pm 1 \cdot 0$ & $1322 \pm 544^{* *}(7)$ \\
Control & $23 \cdot 5 \pm 0 \cdot 5$ & $22 \cdot 3 \pm 0 \cdot 6$ & $496 \pm 210 \quad(8)$ \\
\hline
\end{tabular}

Values are mean \pm s.e.m.

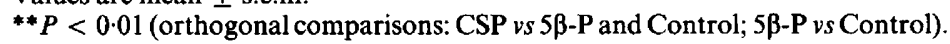

$\uparrow$ Values are number of acute 6-h bleedings. 
and cow nested within treatment by time interaction. Estimates for PGF produced over the 6-h sampling periods on Days 18-20 were generated by sequential summation of PGF concentrations measured in plasma on Days 18-20. Using this method, a series of PGF values were generated over days for each sample within cow. Each PGF value corresponded to the PGF concentration in the respective sample plus a summation of PGF concentrations in all prior samples (accumulated PGF). To provide estimates of temporal changes, progesterone concentrations and accumulated PGF values were analysed by least squares regression analyses, and differences in treatment means were evaluated by orthogonal comparisons (CSP versus $5 \beta-\mathrm{P}$ and Control; $5 \beta-\mathrm{P}$ versus $\mathrm{Control)}$ ). Differences in polynomial regressions were tested by examining for homogeneity of regression between treatment response curves. These data were analysed with time as a continuous, independent variable. Data pertaining to cycle length, days with progesterone concentrations $>1 \mathrm{ng} / \mathrm{ml}$, and mean accumulated PGF (Table 1) as well as effects of age of conceptus on its wet weight, and $\mu \mathrm{g}$ protein produced/mg conceptus wet weight (Table 2 ) were analysed by a one-way analysis of variance. Treatment differences were evaluated by orthogonal comparisons.

\section{Results}

\section{Evaluation of reproductive tracts}

Cows were palpated per rectum following detected oestrus. In all cases, a single regressing CL was detected on the same ovary bearing a functional $\mathrm{CL}$ at surgery. At dissection of reproductive tracts after slaughter, all catheters were intact and patency was verified. General appearance of endometrium and utero-ovarian tissues was normal for all experimental animals.

\section{Effects of intrauterine injections on interoestrous interval and corpus luteum function}

Oestrous cycle lengths immediately preceding the experimental oestrous cycle were not different $(P>0.25)$ amongst cows assigned to the three groups $(20.57 \pm 0.89$ days). Intrauterine administration of CSP to cyclic cows resulted in extended oestrous cycle lengths $(P<0.01)$ of 30 , 31.75 and 38.5 days as compared to cows which received $5 \beta-P(23,25.5$ and 25.5 days $)$ and Control $(22 \cdot 5,24$ and 24 days) injections. No differences were detected $(P>0 \cdot 25)$ in interoestrous intervals between cows of the $5 \beta-P$ and Control groups (Table 1 ).

Analysis of plasma progesterone concentrations verified observations associated with rectal palpations and interoestrous intervals (Fig. 1; Table 1). Function of the CL (progesterone concentrations $>1 \mathrm{ng} / \mathrm{ml}$ ) was maintained for 28,29 and 34 days after CSP treatments, whereas CL lifespans of cows in the $5 \beta-\mathrm{P}(21,22.5$ and 24.5 days $)$ and Control $(21 \cdot 5,22$ and 23.5 days $)$ groups

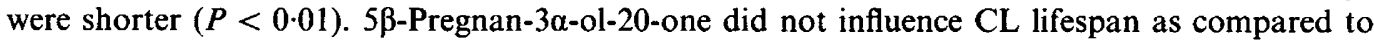
Control cows treated with homologous serum proteins alone. Vena cava catheters were maintained to about Day 21 of the experimental cycle $(21 \cdot 17 \pm 1 \cdot 05$; Fig. 1) when jugular catheters were installed ( 8 of 9 cows). After loss of vena cava catheter patency, 7 of 8 experimental cows exhibited mean \pm s.e.m. jugular concentrations of progesterone of $6 \cdot 1 \pm 1.8 \mathrm{ng} / \mathrm{ml}$. Concentrations of progesterone were $2-10$ times higher in vena cava plasma immediately before failure of the vena cava catheter $(17.5 \pm 6.3 \mathrm{ng} / \mathrm{ml})$ than in jugular plasma.

\section{Effects of intrauterine injections on plasma prostaglandin concentrations}

Analysis of PGF responses suggested that proteins secreted by bovine conceptuses reduced uterine production of PGF (Fig. 2). Circulating PGF exhibits a relatively short half-life (7-8 min; Kindahl, Edqvist, Bane \& Granstrom, 1976) due to its rapid metabolism by the lung and peripheral tissues (Granstrom \& Kindahl, 1982). Therefore, plasma samples from the vena cava were utilized 
for PGF determinations. Higher plasma concentrations of progesterone in vena cava versus jugular vein samples were used as verification of catheter placement before PGF data analysis. The number of cows contributing to PGF responses in vena cava plasma for each group on Days 18, 19 and 20 were: CSP, 2, 2, 2; 5 $\beta$-P, 3, 3, 1; and Control, 3, 3, 2, respectively. A significant treatment by time interaction $(P<0.05)$ was detected for plasma PGF concentrations in the vena cava and supported a role for CSP in the reduction of PGF production. Pulsatile episodes of PGF concentrations in the vena cava were apparent in plasma samples collected from all cows of the $5 \beta-P$ treatment group during Days 18-20. Similarly, spontaneous elevations of PGF in vena cava plasma were detected in 2 of 3,3 of 3 , and 1 of 2 Control cows on Days 18, 19 and 20, respectively. In contrast, no measurable PGF was detected in vena cava plasma from 2 of 2 cows in the CSP treatment group on
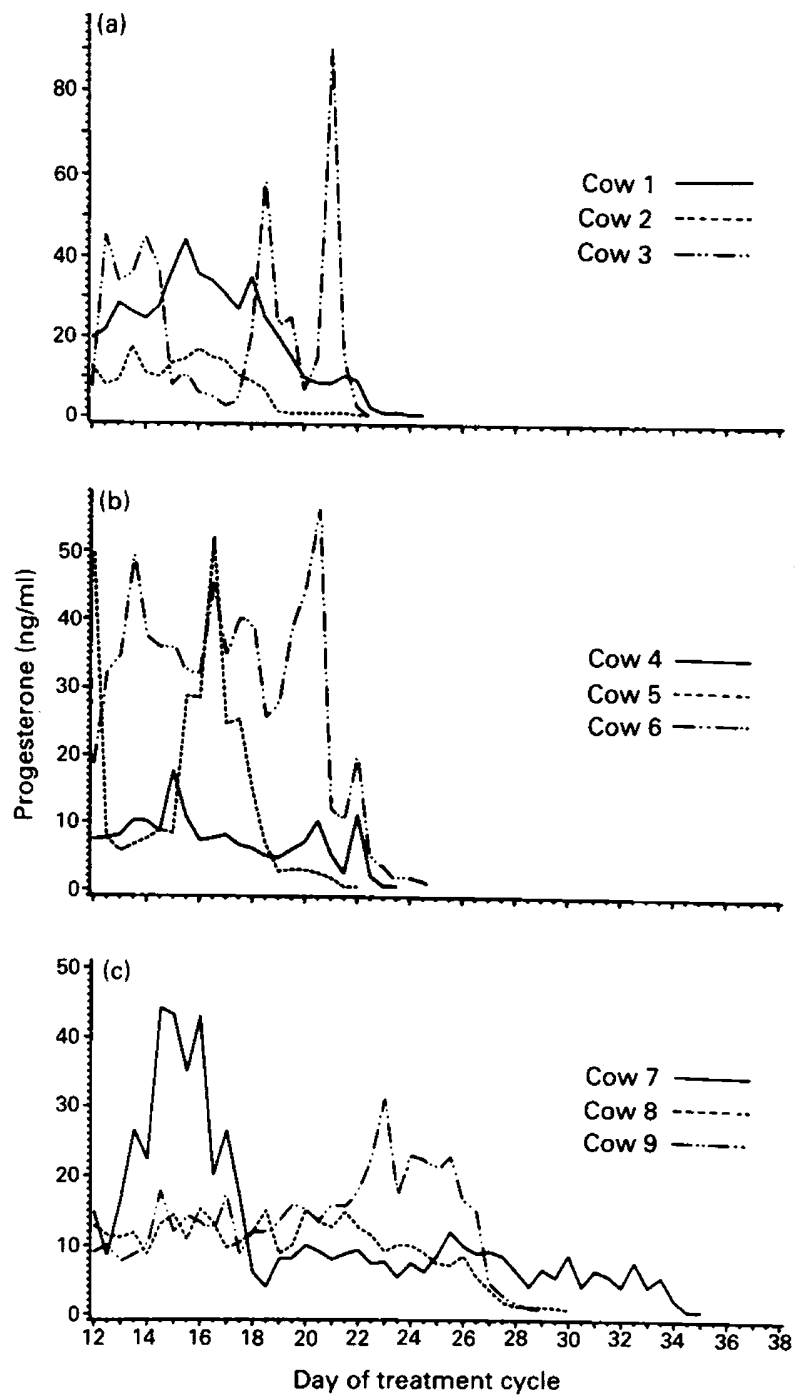

Fig. 1. Least squares means for plasma progesterone concentrations in cyclic cattle ( 3 per group) after intrauterine injections of (a) homologous serum proteins (control), (b) $5 \beta$-pregnan-3a-ol-20-one, or (c) bovine conceptus secretory proteins from Days 15.5 to 21 . The durations (days) of vena cava catheter patency for each cow were 19.5, 22.0 and 22.0 for Cows 1,2 and $3 ; 19 \cdot 5,20 \cdot 0$ and $21 \cdot 0$ for Cows 4,5 and 6 ; and $18 \cdot 0,20 \cdot 5$ and $28 \cdot 0$ for Cows 7,8 and 9 . 

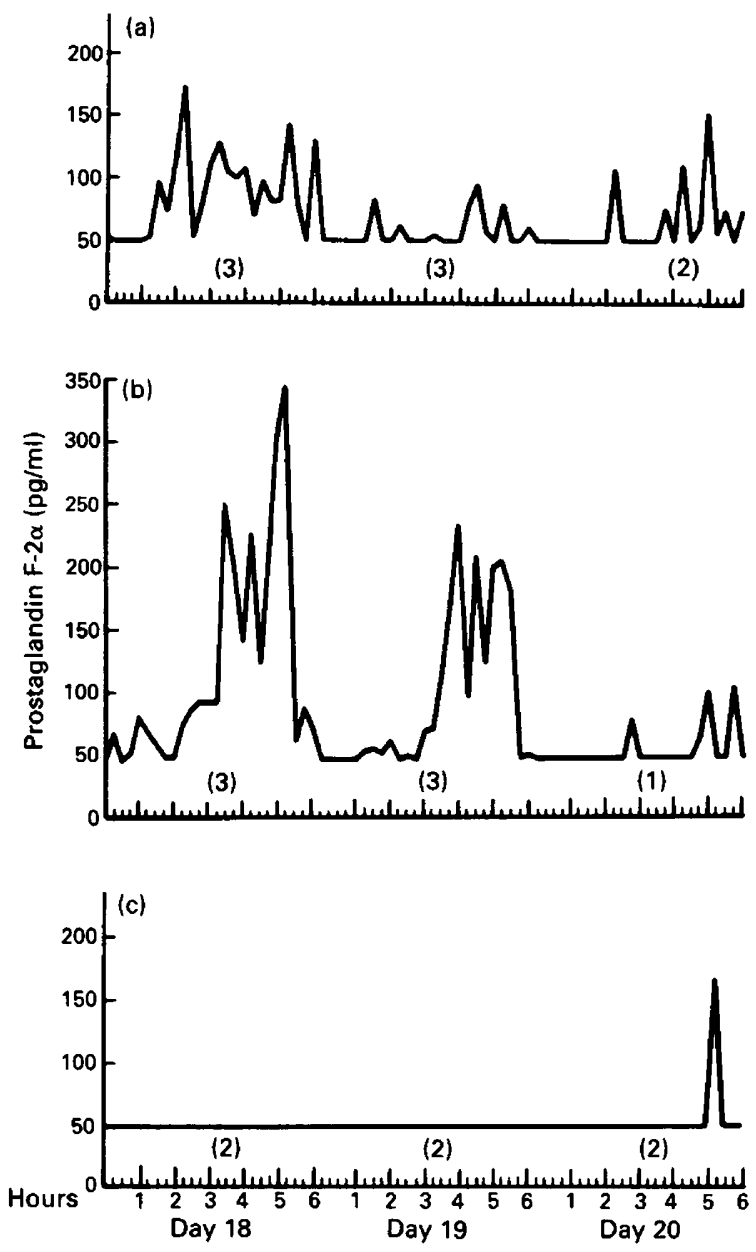

Fig. 2. Least squares means for concentrations of PGF in vena cava plasma collected from experimental cattle every $15 \mathrm{~min}$ for $6 \mathrm{~h}$ on Days 18,19 and 20. Intrauterine treatments with (a) homologous serum proteins (control), (b) $5 \beta$-pregnan-3a-ol-20-one, or (c) conceptus secretory proteins were administered twice daily from Days $15 \cdot 5$ to 21 . Number of cows represented on each day are indicated in parentheses.

Table 2. Bovine conceptus $\dagger$ wet weight and protein production

\begin{tabular}{lccc}
\hline Age (days) & $\begin{array}{c}\text { No. of } \\
\text { cows }\end{array}$ & $\begin{array}{c}\text { Wet weight } \\
(\mathrm{mg})\end{array}$ & $\begin{array}{c}\text { Protein } \\
(\mu \mathrm{g} / \mathrm{mg} \text { wet weight) }\end{array}$ \\
\hline $16 \cdot 5$ & 9 & $31 \cdot 7 \pm 7 \cdot 7$ & $4.9 \pm 2 \cdot 4 \ddagger$ \\
$17 \cdot 0$ & 13 & $35 \cdot 1 \pm 3 \cdot 6$ & $15 \cdot 8 \pm 5 \cdot 2$ \\
$17 \cdot 5$ & 4 & $27.6 \pm 8 \cdot 0$ & $12.0 \pm 4 \cdot 1$ \\
$18 \cdot 0-18.5$ & 6 & $55 \cdot 8 \pm 8 \cdot 6^{*}$ & $15.9 \pm 5 \cdot 3$ \\
\hline
\end{tabular}

Values are mean \pm s.e.m.

†Data from conceptuses collected after superovulation are not included in analysis ( $n=15$ cultures; $22 \cdot 3 \pm 2 \cdot 0 \mu \mathrm{g}$ protein $/ \mathrm{mg}$ wet weight).

${ }^{*} P<0.05$ (orthogonal comparison: $18.0-18.5$ vs $16.5,17.0,17.5$ ).

$\ddagger P<0.05$ (orthogonal comparison: $16 \cdot 5$ ys $17 \cdot 0,17 \cdot 5,18 \cdot 0-18 \cdot 5$ ). 
Days 18 and 19. One plasma sample did contain measurable amounts of PGF in 1 of 2 cows on Day 20. Profiles of PGF concentrations (least squares means) for each group are depicted in Fig. 2. Concentrations of PGF were also accumulated over the 3 days sample and analysed statistically. Orthogonal comparisons of treatment means indicated that intrauterine administration of CSP resulted in a mean accumulation per cow of less PGF than in cows after $5 \beta-P$ and Control treatments (Table 1; $P<0.01$ ). Additionally, accumulation of PGF was greater in cows treated with $5 \beta$-P compared to cows that received homologous serum proteins alone $(P<0.01)$.

\section{Bovine conceptus observations}

Thirty-two conceptuses were classified according to their age (Days 16.5, 17, 17.5 and 18-18.5) at the time of nonsurgical flushing (Table 2). Although conceptus wet weights did not increase significantly until between Day 17.5 and Day 18.0 to 18.5 after insemination, tissue secretory activity ( $\mu \mathrm{g}$ protein produced/mg conceptus wet weight) increased $\sim 3$-fold in conceptuses 17 days and older $(P<0.05)$ compared to those recovered on Day 16.5 .

\section{Discussion}

Maternal recognition of pregnancy occurs by Day 16 to 17 in cattle (Northey \& French, 1980; Betteridge et al., 1980; Dalla Porta \& Humblot, 1983). This represents a critical period during early gestation when production of conceptus signals becomes essential to luteal maintenance and continued endometrial secretory activity (histotroph). A phase of rapid conceptus elongation and differentiation is intimately associated with this period of signal transmission by the bovine conceptus (Chang, 1952; Greenstein \& Foley, 1958a, b; Greenstein, Murray \& Foley, 1958). Developmental stage of the conceptus may therefore determine the timing of conceptus signal. production and secretion during early pregnancy (Bartol et al., 1984).

In the present study, total protein production per $\mathrm{mg}$ of conceptus tissue increased after the initiation of conceptus elongation on Day 16. This increase in protein secretory activity was observed before any detectable increase in conceptus mass (Table 2). Conceptus mass may not be an appropriate index of conceptus expansion since Geisert, Brookbank, Roberts \& Bazer (1982) concluded that the initial rapid elongation of the pig conceptus was due to cellular remodelling and not hyperplasia, whereas subsequent conceptus elongation was associated with increasing DNA and RNA content. In bovine conceptus incubations, $\left[{ }^{3} \mathrm{H}\right]$ leucine incorporation into nondialysable secretory products (presumably proteins) supported an increase in production of labelled proteins from Days 16 to 19 and 22 (Bartol et al., 1984). An increase in conceptus tissue secretory activity therefore occurs concomitantly with elongation of the cow conceptus.

Based on the progesterone profiles (Fig. 1; Table 1) and PGF data (Fig. 2; Table 1), conceptus secretory proteins appeared not to stimulate luteal synthesis of progesterone (luteotrophic), but allowed for extended luteal function via local suppression of spontaneous uterine PGF production (antiluteolytic). A significant reduction in oestradiol-induced uterine PGF production after intrauterine administration of bovine CSP to cyclic cows was demonstrated by Knickerbocker, Thatcher, Bazer, Barron \& Roberts (1984). Collectively, these data indicate that proteins secreted by the bovine conceptus are involved in mediation of antiluteolytic effects during early pregnancy. Reduction in uterine luteolytic activity by conceptus secretory proteins may involve regulation at several levels of the arachidonic acid metabolic cascade (Thatcher et al., 1984; Milvae \& Hansel, 1984), control of endometrial oxytocin and steroid receptor populations (McCracken, Schramm, Barcikowski \& Wilson, 1981; McCracken, 1984) or stimulation of endometrial prostaglandin inhibitors (Wlodawer, Kindahl \& Hamberg, 1976; Shemesh, Hansel \& Strauss, 1984).

In this study, protein signals secreted in culture by elongating cow conceptuses (Days 16.5-18.5) extended luteal function and interoestrous interval to about 30 and 33 days, respectively, when 
administered into the uterine lumen of cyclic cattle on Days 15-21 after oestrus. Similar data were reported by Godkin et al. (1984b); intrauterine administration of the low molecular weight acidic polypeptide, termed ovine trophoblast protein-1 (oTP-1), extended luteal function in cyclic ewes. Roles of specific proteins secreted by the cow conceptus have not been examined. However, several recent reports suggest that there may be similarities in the nature and function of conceptus protein signals in cattle and sheep during early pregnancy.

Major components of the protein synthesized and released in culture by Day 16-24 cow conceptuses are low molecular weight, acidic polypeptides (Bartol et al., 1984), similar in nature to those produced by the elongating sheep conceptus (Days 13-21); Godkin, Bazer, Sessions \& Roberts, 1982; Martal, Charlier, Camous, Fevre \& Heyman, 1984b). When cow (Day 14) and sheep (Day 11-13) trophoblastic vesicles, composed of extraembryonic trophectoderm and endoderm, were transferred and allowed to develop in cyclic cattle and sheep, respectively, a majority of the recipients exhibited prolonged CL maintenance (Heyman, Camous, Fevre, Méziou \& Martal, 1984; Martal et al., 1984b). These data support previous reports (Godkin et al., 1982; Godkin, Bazer \& Roberts, 1984a) that the extraembryonic trophectodermal layer of the conceptus secretes proteinaceous signals responsible for CL maintenance in early pregnancy. In a related study (Martal, Camous, Fevre, Charlier \& Heyman, 1984a), cross-species transfers of cow and sheep trophoblastic vesicles led to extended CL function in about $20 \%$ of ewe and cow recipients. The authors suggested that nonspecific conceptus signals in the cow and ewe were sufficient for maintaining CL function, and the biologically active molecules responsible for CL maintenance in these species may be very similar. Additional support for this argument was obtained when antibodies produced against oTP-1 (Godkin et al., 1984a) were found to cross-react with low molecular weight polypeptides secreted by the bovine conceptus (Helmer, Hansen, Thatcher, Roberts \& Bazer, 1985). These observations indicate that luteal maintenance during early gestation may be achieved by analogous mechanisms in cattle and sheep.

The duration of CL extension in recipient cattle (range 25-37 days) after species-specific transfers of trophoblastic vesicles (Heyman et al., 1984), and transfers of sheep trophoblastic vesicles (31 and 35 days; Martal et al., 1984a) is similar to luteal lifespans achieved in this study (Fig. 1; Table 1) after intrauterine treatments with pooled bovine conceptus secretory proteins in cyclic cattle (range $28-34$ days).

In contrast to the observed antiluteolytic activity of conceptus secretory proteins, $5 \beta$ pregnan-3 $\alpha$-ol-20-one, a major steroid produced by the conceptus, did not influence CL lifespan, cycle length or decrease uterine PGF production. In fact, $5 \beta$-pregnan-3 $\alpha$-ol-20-one apparently increased uterine PGF production. It is possible that the progestational activity of this $5 \beta$-reduced progestagen was sufficient to stimulate endometrial accumulation of lipid stores and prostaglandin precursors, thereby resulting in a greater uterine ability to synthesize PGF.

In conclusion, intrauterine administration of bovine conceptus secretory proteins to cyclic cattle was shown to extend CL lifespan and interoestrous interval, and attenuate spontaneous uterine PGF production (PGF in vena cava plasma). These results provide strong evidence that protein signals secreted by the conceptus during the first 2-3 weeks of gestation in the cow are required for the establishment of pregnancy.

We thank Ms Carol S. Underwood and Mr Thomas Bruce for help in the collection of data, assays and animal care during the experiment; and Dr Kenneth Kirton of The Upjohn Company, Kalamazoo, MI, and Dr M. Reyes de Manzo of the Universidad Central de Venezuela, Marachiebo, for gifts of antisera to PGF-2 $\alpha$ and progesterone, respectively. This work was supported in part by a grant to W.W.T. from The Upjohn Company, Kalamazoo, Michigan, U.S.A., and National Institutes of Health grant no. HD-10436 to R.M.R. and F.W.B. This is Journal Series Paper No. 6388 of the University of Florida Agricultural Experiment Station. 


\section{References}

Bartol, F.F., Thatcher, W.W., Lewis, G.S., Bliss, E.L., Drost, M. \& Bazer, F.W. (1981) Effect of estradiol-17 $\beta$ on PGF and total protein content in bovine uterine flushings and peripheral plasma concentration of 13,14-dihydro-15-keto-PGF ${ }_{2 a}$. Theriogenology 15, 345-358.

Bartol, F.F., Roberts, R.M., Bazer, F.W., Lewis, G.S., Godkin, J.D. \& Thatcher, W.W. (1984) Characterization of proteins produced in vitro by peri-attachment bovine conceptuses. Biol. Reprod. 32, 681-694.

Betteridge, K.J., Eaglesome, M.D., Randall, G.C.B. \& Mitchell, D. (1980) Collection, description and transfer of embryos from cattle 10-16 days after oestrus. J. Reprod. Fert. 59, 205-216.

Chang, M.C. (1952) Development of bovine blastocyst with a note on implantation. Anat. Rec. 113, 143-153.

Chenault, J.R. (1980) Steroid metabolism by the early bovine conceptus. 1. $5 \beta$-reduction of neutral C19-steroids. J. Steroid Biochem. 13, 499-506.

Chenault, J.R. (1983) Response of bovine corpora lutea to intrauterine prostaglandin $\mathrm{E}_{2}$ infusion. J. Anim. Sci. 57 (Suppl. 1), 323, Abstr.

Chenault, J.R., Van Ravenswaay, F. \& Campbell, C.L. (1984) Effect of intrauterine infused $\mathrm{PGE}_{2}$ on plasma progesterone and 13,14-dihydro-15-keto-PGF $F_{2 \alpha}$ responses to estradiol-17ß or $\mathrm{PGF}_{2 a}$ responses to estradiol-17 $\beta$ or $\mathrm{PGF}_{2 \alpha}$ administration. J. Anim. Sci. 59 (Suppl. 1), 330, Abstr.

Dalla Porta, M.A. \& Humblot, P. (1983) Effect of embryo removal and embryonic extracts or $\mathrm{PGE}_{2}$ infusions on luteal function in the bovine. Theriogenology 19, 122, Abstr.

Dulbecco, R. \& Vogt, M. (1954) Plaque formation and isolation of pure lines with poliomyelitis viruses. $J$. exp. Med. 99, 167-182.

Eley, R.M., Thatcher, W.W., Bazer, F.W. \& Fields, M.J. (1983) Steroid metabolism by the bovine uterine endometrium and conceptus. Biol. Reprod. 28, 804-816.

Ellinwood, W.E., Nett, T.M. \& Niswender, G.D. (1979) Maintenance of the corpus luteum of early pregnancy in the ewe. I. Luteotropic properties of embryonic homogenates. Biol. Reprod. 21, 281-288.

Gadsby, J.E., Heap, R.B. \& Burton, R.D. (1980) Oestrogen production by blastocyst and early embryonic tissue of various species. J. Reprod. Fert. 60, 409-417.

Geisert, R.D., Brookbank, J.W., Roberts, R.M. \& Bazer, F.W. (1982) Establishment of pregnancy in the pig, II. Cellular remodelling of the porcine blastocyst during elongation on day 12 of pregnancy. Biol. Reprod. 27, 941-955.

Gimenez, T. \& Henricks, D.M. (1983) Prolongation of the luteal phase by prostaglandin $E_{2}$ during the estrous cycle in the sow. A preliminary report. Theriogenology 19, 693-700.

Godkin, J.D., Bazer, F.W., Sessions, F. \& Roberts, R.M. (1982) Purification and properties of a major, low molecular weight protein released by the trophoblast of sheep blastocysts at Day 13-21. J. Reprod. Fert. 65, $141-150$.

Godkin, J.D., Bazer, F.W. \& Roberts, R.M. (1984a)
Ovine trophoblast protein 1, and early secreted blastocyst protein, binds specifically to uterine endometrium and affects protein synthesis. Endocrinology 114, $120-130$.

Godkin, J.D., Bazer, F.W, Thatcher, W.W. \& Roberts, R.M. (1984b) Proteins released by cultured Day 15-16 conceptuses prolong luteal maintenance when introduced into the uterine lumen of cyclic ewes. $J$. Reprod. Fert. 71, 57-64.

Granstrom, E. \& Kindahl, H. (1982) Species differences in circulating prostaglandin metabolites. Relevance for the assay of prostaglandin release. Biochim. Biophys. Acta 713, 555-569.

Greenstein, J.S. \& Foley, R.C. (1958a) The early embryology of the cow with notes on comparable human development. Int. J. Fertil. 3, 67-79.

Greenstein, J.S. \& Foley, R.C. (1958b) Early embryology of the cow. I. Gastrula and primitive streak stages. $J$. Dairy Sci. 41, 409-421.

Greenstein, J.S., Murray, R.W. \& Foley, R.C. (1958) Observations on the morphogenesis and histochemistry of the bovine preattachment placenta between 16 and 33 days of gestation. Anat. Rec. 132, 321-341.

Helmer, S.D., Hansen, P.J., Thatcher, W.W., Roberts, R.M. \& Bazer, F.W. (1985) Similarities between ovine and bovine conceptus secretory proteins (oCSP, bCSP) associated with luteal maintenance. $J$. Anim. Sci. 61 (Suppl. 1), 400-401, Abstr.

Henderson, K.M., Scaramuzzi, R.J. \& Baird, D.T. (1977) Simultaneous infusion of prostaglandin $\mathrm{E}_{2}$ antagonizes the luteolytic action of prostaglandin $F_{2 a}$ in vitro. J. Endocr. 72, 379-383.

Heyman, Y., Camous, S., Fevre, J., Méziou, W. \& Martal, J. (1984) Maintenance of the corpus luteum after uterine transfer of trophoblastic vesicles to cyclic cows and ewes. J. Reprod. Fert. 70, 533-540.

Kindahl, H., Edqvist, L.E., Bane, A. \& Granstrom, E. (1976) Blood levels of progesterone and 15-keto13,14-dihydro-prostaglandin $\mathbf{F}_{2 \alpha}$ during the normal oestrous cycle and early pregnancy in heifers. Acta endocr., Copenh. 82, 134-149.

Knickerbocker, J.J., Thatcher, W.W., Bazer, F.W., Barron, D.H. \& Roberts, R.M. (1984) Inhibition of estradiol-17 $\beta$ induced uterine prostaglandin $F_{2 \alpha}$ production by bovine conceptus secretory proteins. $J$. Anim. Sci. 59 (Supp1. 1), 368, Abstr.

Lewis, G.S., Thatcher, W.W., Bazer, F.W. \& Curl, J.S. (1982) Metabolism of arachidonic acid in vitro by bovine blastocysts and endometrium. Biol. Reprod. 27, 431-439.

Lowry, O.H., Rosebrough, N.C., Farr, A.L. \& Randall, R.J. (1951) Protein measurement with the folin phenol reagent. J. biol. Chem. 193, 266-275.

Marsh, J.M. (1970) The stimulatory effect of prostaglandin $\mathrm{E}_{2}$ on adenyl-cyclase in the bovine corpus luteum. FEBS Letters 7, 283-286.

Martal, J., Lacroix, M., Loudes, C., Saunier, M. \& Wintenberger-Torres, S. (1979) Trophoblastin, an antiluteolytic protein present in early pregnancy in sheep. J. Reprod. Fert. 56, 63-73.

Martal, J., Camous, S., Fevre, J., Charlier, M. \& 
Heyman, Y. (1984a) Specificity of embryonic signals maintaining the corpus luteum in early pregnancy in ruminants. Proc. 10th Int. Congr. Anim. Reprod. \& A.I., Urbana 3, 510, Abstr.

Martal, J., Charlier, M., Camous, S., Fevre, J. \& Heyman, Y. (1984b) Origin of embryonic signals allowing the establishment of pregnancy corpus luteum in ruminants. Proc. 10th Int. Congr. Anim. Reprod. \& A.I., Urbana 3, 509, Abstr.

McCracken, J.A. .(1984) Research review: update on luteolysis-receptor regulation of pulsatile secretion of prostaglandin $F_{2 a}$ from the uterus. In Research in Reproduction, No. 2, pp. 1-2, Ed. R. G. Edwards. The International Planned Parenthood Foundation, London.

McCracken, J.A., Schramm, W., Barcikowski, B. \& Wilson, L. (1981) The identification of prostaglandin $F_{2 a}$ as a uterine luteolytic hormone and the hormonal control of its synthesis. Acta vet. scand., Suppl. 77, 71-88.

Milvae, R.A. \& Hansel, W. (1984) A luteolytic role for lipoxygenase products of arachidonic acid metabolism. J. Anim. Sci. 59 (Suppl. 1), 335, Abstr.

Northey, D.L. \& French, L.R. (1980) Effect of embryo removal and intrauterine infusion of embryonic homogenates on the lifespan of the bovine corpus luteum. J. Anim. Sci. 50, 298-302.

Reynolds, L.P., Stigler, J., Hoyer, G.L., Magness, R.R., Huie, J.M., Huecksteadt, T.P., Whysong, G.L., Behrman, H.R. \& Weems, C.W. (1981) Effects of $\mathrm{PGE}_{1}$ or $\mathrm{PGE}_{2}$ on $\mathrm{PGF}_{2 a}$-induced luteolysis in non-bred ewes. Prostaglandins 21, 957-972.

Reynolds, L.P., Robertson, D.A. \& Ford, S.P. (1983) Effects of intrauterine infusion of oestradiol-17 $\beta$ and prostaglandin E-2 on luteal function in non-pregnant heifers. J. Reprod. Fert. 69, 703-709.

Rowson, L.E.A. \& Moor, R.M. (1967) The influence of embryonic tissue homogenates infused into the uterus on the lifespan of the corpus luteum in the sheep. J. Reprod. Fert. 13, 511-516.

SAS Institute Incorporated (1982) SAS Users Guide: Statistics, Cary, North Carolina.

Shemesh, M., Hansel, W. \& Strauss, J.F., III (1984) Modulation of bovine placental prostaglandin synthesis by an exogenous inhibitor. Endocrinology 115, 1401-1405.

Shemesh, M., Milaguir, F., Ayalon, N. Hansel, W. (1979) Steroidogenesis and prostaglandin synthesis by cultured bovine blastocysts. J. Reprod. Fert. 56, 181-185.

Thatcher, W.W., Wolfenson, D., Curl, J.S., Rico, L.E., Knickerbocker, J.J., Bazer, F.W. \& Drost, M. (1984) Prostaglandin dynamics associated with development of the bovine conceptus. Anim. Reprod. Sci. 7, 149-176.

Wlodawer, P., Kindahl, H. \& Hamberg, M. (1976) Biosynthesis of prostaglandin $F_{2 a}$ from arachidonic acid and prostaglandin endoperoxides in the uterus. Biochim. Biophys. Acta. 431, 603-614.

Wolfenson, D., Thatcher, W.W., Drost, M., Caton, D., Foster, D.B. \& LeBlanc, M.M. (1985) Characteristics of prostaglandin $F$ measurements in the ovarian circulation during the oestrous cycle and early pregnancy in the cow. J. Reprod. Fert. 75, 491-499.

Received 28 August 1985 